\title{
Tables, Figures, Maps
}

\section{TABLES}

1. Native/Nonnative Populations in the Three Villages, 1982

2. Estimated Annual Meat Consumption by Dogs in the Three Villages, 1965 and 1982, and Projected Consumption for 1982, Assuming Total Dog Traction

3. Expenses Incurred by Families and Walrus/ Bearded Seal Crews for Extraction Trips, Unalakleet, Wainwright, and Gambell, 1982

4. Annual Equipment Expenses for Subsistence Extraction, Unalakleet, Wainwright, and Gambell, 1982

5. Estimate of Annual Subsistence Consumption per Household, Gambell and Unalakleet, 1982

6. Infrastructure, Unalakleet, Gambell, and Wainwright, 1982

7. Ownership of Businesses, Unalakleet, Gambell, and Wainwright, 1982

8. Full-time Employment, Unalakleet, Gambell, and Wainwright, 1982

9. Employment in Private, Family-held, and Family-operated Businesses, in Unalakleet, Gambell, and Wainwright, 1982

10. The Household Balance Sheet: Relations between Expenses and Income in Unalakleet, Gambell, and Wainwright, 1982

11. Some Food Prices in Unalakleet, Wainwright, and Newport Beach, California, 1982

12. Commercial Salmon Harvest, Average Numbers of Fish and Dollars, Unalakleet, 1961-1982 
13. Comparisons of Salmon Catches, Total Values, and Prices per Fish, Unalakleet, 1981-82 Seasons

14. A Commercial Salmon Fisherman's Start-up Costs, Unalakleet Prices, 1982

15. A Commercial Salmon Fisherman's Annual Operating and Maintenance Costs, Unalakleet Prices, 1982

16. Equipment Costs to Penetrate the Commercial Herring Fishery, Unalakleet, 1982

17. Average Household Sizes in Unalakleet, Gambell, Wainwright, and the United States, at Unequal Intervals, 1955-1982

18. Household Composition in Unalakleet, Wainwright, Gambell, and the United States, 1982

19. Populations, Birth/Death Ratios and OutMigration, Unalakleet, Gambell, and Wainwright, 1982-1987

20. Native Employment, Full-time for 1982 and Estimates of Full-time Equivalents for 1987 in Gambell, Wainwright, and Unalakleet

21. Public Sector Transfers: Combined Values of Food Stamps, Aid to Families with Dependent Children, and Adult Public Assistance in Gambell, Wainwright, and Unalakleet, 1984-1987

22. Market Basket Prices, Three Villages and Newport Beach, California, 1988

C1. Comparisons of the Three Climates

C2. Availability and Harvests of Marine Mammals in Unalakleet, Wainwright, and Gambell, 1981-82

C3. Availability and Harvests of Land Mammals in Unalakleet, Wainwright, and Gambell, 1981-82

C4. Availability and Harvests of Fish in Unalakleet, Wainwright, and Gambell, 1981-82

C5. Average Weights, Calories per Edible Pound, Relative Concentrations of Vitamins, Abundance, 
and Extractability of Several Important Arctic and Subarctic Fish Genuses

C6. Availability and Harvests of Birds in Unalakleet, Wainwright, and Gambell, 1982

C7. Comparisons of the Extraction of Commonly Available Avian Species in Gambell, Wainwright, and Unalakleet, 1982

C8. Marine Invertebrates Harvested in Gambell, Unalakleet, and Wainwright, 1982

C9. Marine Plants and Land Plants Harvested in Unalakleet, Gambell, and Wainwright, 1982

\section{FIGURES}

1. Mandated and Optional Governmental and Economic Organizations of Contemporary Eskimo Villages

2. Gambell and Total St. Lawrence Island Population, over 130 Years (1852-1982), at Unequal Intervals

3. Unalakleet Population, over 146 Years (18361982), at Unequal Intervals

4. Wainwright Population, over 93 Years (1890 1983), at Unequal Intervals

5. Population Trend Lines, Unalakleet, Gambell, and Wainwright (1880-1982)

6. Yearly Subsistence Cycles, Three Villages, 1981-82

7. Typical Walrus (Beluga, Bearded Seal) Crews at Gambell, Wainwright, and Unalakleet, 1982

8. Typical Whaling Crew Composition in Wainwright and Gambell, 1982

9. Representative Young-Bird and Egg-Collecting Crews, Gambell, 1982

10. Subsistence Seine Techniques, Unalakleet, 1982

11. Schematic Representation of Kindreds, Unalakleet and Wainwright, 1982 
12. A St. Lawrence Island Patriclan with Clan Segments in Gambell and Savoonga, 1982

13. A Kinship Sharing Network, Gambell, 1982

\section{MAPS}

1. Location of the Villages in the Study

25

2. Gambell

3. St. Lawrence Island Region, Bearing Sea

4. Unalakleet

5. Eastern Norton Sound Region

6. Wainwright

7. Chukchi Sea Region, Arctic Ocean

8. Distribution of Unalit (Yupik), Malemiut (Inupiaq), and Kawerak (Inupiaq) about 1836 (from Nelson 1899)

9. Total Resource Extraction Area of Unalakleet Villagers, 1982

10. Total Resource Extraction Area of Gambell Villagers, 1982

11. Total Resource Extraction Area of Wainwright Villagers, 1982

C1. Vegetation Areas of the Three Villages 